\title{
PERENCANAAN JARINGAN PERPIPAAN AIR MINUM MENGGUNAKAN APLIKASI WATERCAD V8-I
}

\author{
Wesli $^{1)}$, Fasdarsyah ${ }^{2)}$, Indra Kurniawan ${ }^{3)}$, Khairullah Yusuf ${ }^{4)}$, Said Jalalul Akbar ${ }^{5)}$,

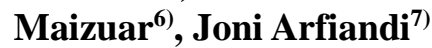 \\ 1,2,3,4,5,6,7) Jurusan Teknik Sipil, Universitas Malikussaleh \\ Email: wesli@unimal.ac.id ${ }^{1)}$,fasdarsyah@unimal.ac.id ${ }^{2)}$

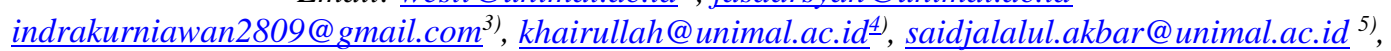 \\ maizuar@unimal.ac.id ${ }^{4)}$, jonicaleue@gmail.com ${ }^{6)}$ \\ Corresponding Author: wesli@ unimal.ac.id
}

DOI: http://dx.doi.org/10.29103/tj.v11i2.554

(Received: June 2021 / Revised: August 2021 / Accepted: August 2021)

\begin{abstract}
Abstrak
Pelayanan kebutuhan air di wilayah IKK Bukit Oregon kurang memadai diduga jaringan pipa menjadi pokok masalahnya sehingga berdasar hal tersebut maka diperlukan evaluasi jaringan perpipaan air minum dan design dibuat dengan menggunakan software Aplikasi Watercad V8-I dan ingin diketahui seberapa besar kebutuhan debit pada proyeksi tahun 2030 termasuk kapasitas pompa dan jenis pipa transmisinya. Hasil pengamatan secara langsung di wilayah studi pada pelayanan terdapat permasalahan yang terjadi pada pipa transmisi, yaitu pipa dari intake (sumber air baku utama) menuju ke Instalasi Pengolahan Air (IPA) yang akan di distribusikan ke masyarakat. Permasalahan yang terjadi adalah pipa induk tersebut mengalami kebocoran akibat umur teknis pipa yang sudah tua. Meningkatnya jumlah penduduk sama halnya semakin meningkatnya pemenuhan akan kebutuhan air bersih. Permasalahan tersebut harus ditanggulangi dengan pergantian pipa dengan jenis dan diameter yang tepat serta kapasitas pompa yang sesuai hasil menggunakan software Watercad V8-i. Dari hasil perhitungan analisa pertumbuhan penduduk pada tahun 2030 dengan jumlah pelanggan 96.770 jiwa kebutuhan air mencapai 102,476 liter/detik. Sistem transmisi menggunakan sistem pompa dengan kapasitas terpasang 90 liter/detik. Jenis pipa yang dipakai untuk pipa transmisi menggunakan pipa HDPE dengan diameter $350 \mathrm{~mm}$.
\end{abstract}

Kata kunci: evaluasi, air bersih, perpipaan, pompa, Watercad V8-i

\begin{abstract}
The service for water needs in the IKK Bukit Oregon area is inadequate, it is suspected that the pipeline network is the main problem, so based on this, it is necessary to evaluate the drinking water piping network and the design is made using the Watercad V8-I application software and wants to know how much the demand for discharge in the 2030 projection includes pump capacity and type of transmission pipe. The results of direct observations in the study area on the service there are problems that occur in the transmission pipe, namely the pipe from the intake (main raw water source) to the Water Treatment Plant (IPA) which will be distributed to the community. The problem that occurs is that the main pipe has a leak due to the technical age of the pipe which is old. The increasing population is the same as the increasing fulfillment of clean water needs. These problems must be overcome by changing the pipe with the right type and diameter and the pump capacity according
\end{abstract}


to the results using the Watercad V8-i software. From the calculation results of population growth analysis in 2030 with the number of customers 96,770 people, water needs reach 102,476 liters/second. The transmission system uses a pump system with an installed capacity of 90 liters/second. The type of pipe used for the transmission pipe uses HDPE pipe with a diameter of $350 \mathrm{~mm}$.

Keywords: evaluation, clean water, piping, pump, Watercad V8-i

\section{Latar Belakang}

Perencanaan air bersih ini dilakukan pada tiap tahunnya, namun di Instalasi Kota Kecamatan (IKK) Bukit Oregon Kabupaten Aceh Tengah memiliki kapasitas $90 \mathrm{~L} /$ detik sehingga memungkinkan penggunaan untuk 5 sampai 10 tahun ke depannya, dengan proyeksi penduduk yang akan dilakukan. Pemilihan lokasi IKK Bukit Oregon Kabupaten Aceh Tengah ini adalah terdapatnya masalah yang dialami masyarakat dari tidak adanya air yang keluar dari pipa induk, maka dari itu pipa tersebut diganti dengan pipa yang baru dengan material yang lebih kuat dan tahan lama. Untuk pipa lama tersebut jenis material PVC yang mudah rapuh dan tidak tahan lama. Material yang baru yang akan digunakan adalah material berjenis HDPE yang kuat dan tahan lama (Kementerian Pekerjaan Umum dan Perumahan Rakyat, 2020).

Pertumbuhan jumlah penduduk yang diikuti dengan meningkatnya keadaan sosial ekonomi masyarakat di Kabupaten Aceh Tengah menyebabkan peningkatan kebutuhan terhadap air baik dari segi kualitas maupun kuantitas. Permasalahan tersebut harus disesuaikan dengan peningkatan kinerja perusahaan terutama dalam pemilihan peralatan pompa dan transmisi air. Pertumbuhan jumlah penduduk tersebut harus disesuiakan dengan debit ketersediaan air yang ada di danau laut tawar. Debit ketersediaan air di danau Laut Tawar harus melebihi dari kapasitas pertumbuhan penduduk tersebut, sehingga kebutuhan air di masyarakat terpenuhi. Kebutuhan air bersih dari tahun ke tahun meningkat seiring dengan peningkatan jumlah penduduk di wilayah studi (Wigati, Restu, 2015).

Tujuan penelitian ini adalah untuk mengevaluasi jaringan perpipaan yang ada dalam upaya pelayanan kebutuhan air bersih pada tahun 2030 dan untuk mengetahui besanya kemampuan tingkat pelayanan PDAM terhadap kebutuhan air bersih pada tahun 2030 .

\section{Metode Penelitian}

Dalam melakukan penelitian ini diawali dengan pengumpulan data berupa data primer dan data sekunder di mana data primer berupa data yang diperoleh langsung dari hasil wawancara dan hasil pengamatan langsung di lapangan berupa hasil kuesioner, data eksisting sumber air rencana, data lokasi sekitar sumber dan kebutuhan air serta keadaan sekitar sumber. Sementara data sekunder merupakan data pendukung yang diperoleh dari instansi terkait berupa laporan kegiatan, standar dan peraturan seperti data kependudukan, perekonomian, fasilitas umum, sarana dan prasarana wilayah studi, data kondisi geografis atau data luas wilayah, peta situasi dan topografi lokasi, data perencanaan pemanfaatan sumber air bersih.

Analisa dilakukan terhadap data-data dan membandingkan data yang terkumpul dengan teori yang ada di literatur air bersih, dari hasil tersebut dievaluasi. Analisa akan difokuskan pada hal-hal yang berhubungan dengan 
sumber air baku, jumlah penduduk ke depan, sarana dan prasarana, pengelolaan air bersih/minum dan sistem penyaluran air bersih serta faktor-faktor lain yang mempengaruhi sistem penyediaan air bersih. Dari hasil analisa dan evaluasi kondisi eksisting akan dihasilkan dan ditentukan suatu konsep sistem penyediaan sarana dan prasarana air bersih. Data yang digunakan sebaiknya adalah data observasi merupakan teknik yang dipergunakan untuk mendapatkan data dengan pengamatan secara langsung (Asgar, 2016)

Menurut Permen PU No. 18/PRT/M/2007 metode ini mengasumsikan pertumbuhan penduduk yang jumlahnya konstan dari tahun ke tahun. Metode linear diperlihatkan pada persamaan (1) dan (2) sebagai berikut:

$$
\begin{aligned}
& P_{n}=P_{0}+(n \times r) \\
& r=P_{t}-P_{0}
\end{aligned}
$$

Sementara pada metode geometrik mengasumsikan tingkat pertumbuhan penduduk tiap tahunnya akan selalu proporsional dengan jumlah penduduk tahun sebelumnya. Metode geometrik diperlihatkan pada persamaan (3) dan (4) sebagai berikut:

$$
\begin{aligned}
& P_{n}=P_{t}(1+r)^{n} \\
& r=\left[\left(\frac{P_{t}}{P_{0}}\right)^{1 / t}-1\right] \times 100 \%
\end{aligned}
$$

di mana $P_{n}$ adalah Jumlah penduduk pada proyeksi tahun ke-n, $P_{0}$ adalah Jumlah penduduk pada awal tahun data, $P_{t}$ adalah Jumlah penduduk pada tahun data berikutnya, $r$ adalah Laju pertumbuhan penduduk rata-rata dan $n$ adalah Jumlah waktu tahun proyeksi serta $t$ adalah Selang waktu tahun data.

Pada perencanaan sistem distribusi air bersih, kategori kegiatan perencanaan untuk sistem distribusi air bersih/minum ada dua kategori yaitu perencanaan pada daerah yang belum ada sistem distribusi perpipaan sama sekali atau biasa disebut sebagai Green Area dan perencanaan pada daerah yang sudah ada sistem distribusi sebelumnya dan sifat perencanaan adalah mengembangkan sistem yang sudah ada (Dharmasetiawan, Martin, 2004).

Air bersih adalah air yang memenuhi persyaratan kesehatan bagi Sistem Penyediaan Air Minum (SPAM), dengan persyaratan kualitas air yang meliputi kualitas fisika, mikrobiologis, kimiawi, dan radioaktif yang dimuat dalam parameter wajib dan parameter tambahan sehingga apabila dikonsumsi tidak menimbulkan efek samping. (Peraturan Menteri Kesehatan Republik Indonesia, 2010). Pengertian air minum adalah air yang kualitasnya memenuhi syarat-syarat kesehatan yang dapat diminum. Alasan kesehatan dan teknis yang mendasari penentuan standar kualitas air minum adalah efek dari setiap parameter jika melebihi dosis yang telah ditetapkan. (Maryanto, Harry, 2013)

Penggunaan data survey jam puncak untuk pemakaian air akan dapat menentukan kondisi reservoir sesuai dengan signifikansi pada analisis data kuesioner (Zalzilah, Ulfani, 2018).

Debit rata-rata pada sambungan rumah (SR) akan lebnih tinghgi apabila pengoperasian pompa dalam waktu yang lebih lama dengan tinggi tekan air akan maksimum (Zamzami, 2007). 
Penentuan dimensi perpipaan transmisi dan distribusi diperlihatkana pada persamaan (5) sebagai berikut:

$$
Q=V \times A
$$

di mana $\mathrm{Q}$ adalah Debit aliran dalam pipa $\left(\mathrm{m}^{3} / \mathrm{det}\right)$, V adalah Kecepatan aliran dalam pipa $(\mathrm{m} / \mathrm{det})$, A adalah Luas penampang pipa $\left(1 / 4 \pi D^{2}\right)\left(\mathrm{m}^{2}\right)$ dan $\mathrm{D}$ adalah Diameter pipa (m).

Langkah-langkah yang dilakukan dalam menganalisis data adalah menghitung debit sumber air rencana secara langsung di lapangan, mendata jumlah penduduk dan jumlah pelanggan yang ada di daerah studi, mengambil titik koordinat dan elevasi wilayah studi, mengukur jarak sumber air rencana ke reservoir, menghitung atau memproyeksikan jumlah penduduk dan jumlah kebutuhan air sampai tahun 2030, menggambar desain skematik rencana distribusi air menggunakan aplikasi autoCad dan mengolah data dengan menggunakan program Watercad $V 8-i$.

\section{Hasil dan Pembahasan}

Hasil yang diperoleh dari penelitian ini berupa proyeksi pertumbuhan penduduk dengan metode linear dan metode Geometrik. Berdasarkan proyeksi pertumbuhan penduduk maka dapat dihasilkan proyeksi jumlah pelanggan dan dapat diproyeksikan kebutuhan air bersih dan selanjutnya diperoleh hasil disain jaringan pipa serta dilakukan simulasi dan dapat dihasilkan water balance.

\subsection{Proyeksi Pertumbuhan Penduduk}

Untuk menghitung analisa proyeksi pertumbuhan penduduk tahun 2030 digunakan data penduduk per kecamatan yang ditinjau selama 10 tahun sebelumnya, yaitu mulai tahun 2010 sampai dengan tahun 2019 yang bersumber dari data BPS (Badan Pusat Statistik), 2020.

Tabel 1 Data penduduk IKK Bukit Oregon

\begin{tabular}{llcccccccccc}
\hline \multirow{2}{*}{ No. } & \multirow{2}{*}{ Kecamatan } & \multicolumn{10}{c}{ Jumlah Penduduk } \\
\cline { 3 - 11 } & 2010 & 2011 & 2012 & 2013 & 2014 & 2015 & 2016 & 2017 & 2018 & 2019 \\
\hline 1. & Lut Tawar & 17.960 & 18.372 & 18.858 & 19.005 & 19.367 & 19.736 & 20.113 & 20.635 & 20.887 & 21.285 \\
\hline 2. & Kebayakan & 14.041 & 14.362 & 14.742 & 14.857 & 15.140 & 15.428 & 15.722 & 16.131 & 16.326 & 16.637 \\
\hline 3. & Bebesen & 34.342 & 35.129 & 36.060 & 36.340 & 37.033 & 37.739 & 38.458 & 39.437 & 39.938 & 40.699 \\
\hline & Total & 66.343 & 67.863 & 69.660 & 70.202 & 71.540 & 72.903 & 74.293 & 76.203 & 77.151 & 78.621 \\
\hline
\end{tabular}

Sumber: BPS Aceh Tengah Tahun 2020

\subsubsection{Analisa proyeksi pertumbuhan penduduk Metode Linear}

Pertumbuhan penduduk wilayah perencanaan diproyeksikan dari tahun 2020 hingga tahun 2030 seperti diperlihatkan pada Tabel 2.

Tabel 2 Jumlah penduduk per kecamatan dengan Metode Linear

\begin{tabular}{ccccc}
\hline \multirow{2}{*}{ Tahun } & \multicolumn{3}{c}{ Kecamatan } & \multirow{2}{*}{ Total } \\
\cline { 2 - 4 } & Lut Tawar & Kebayakan & Bebesen & \\
\hline 2020 & 21.654 & 16.925 & 41.405 & 79.985 \\
\hline 2021 & 22.024 & 17.214 & 42.112 & 81.349 \\
\hline 2022 & 22.393 & 17.502 & 42.818 & 82.714 \\
\hline
\end{tabular}

Evaluasi Perpipaan Air Minum Menggunakan Aplikasi Watercad V8-i - Wesli, Indra Kurniawan, Said Jalalul Akbar, Maizuar, Khairullah Yusuf, Joni Arfiandi 


\begin{tabular}{lllll}
\hline 2023 & 22.763 & 17.791 & 43.524 & 84.078 \\
\hline 2024 & 23.132 & 18.079 & 44.231 & 85.442 \\
\hline 2025 & 23.502 & 18.368 & 44.937 & 86.806 \\
\hline 2026 & 23.871 & 18.656 & 45.643 & 88.171 \\
\hline 2027 & 24.241 & 18.945 & 46.350 & 89.535 \\
\hline 2028 & 24.610 & 19.233 & 47.056 & 90.899 \\
\hline 2029 & 24.979 & 19.521 & 47.762 & 92.263 \\
\hline 2030 & 25.349 & 19.810 & 48.469 & 93.627 \\
\hline
\end{tabular}

\subsubsection{Analisa Proyeksi Pertumbuhan Penduduk Metode Geometrik}

Pertumbuhan penduduk wilayah perencanaan diproyeksikan dari tahun 2020 hingga tahun 2030 seperti diperlihatkan pada Tabel 3.

Tabel 3 Jumlah Penduduk Per Kecamatan Dengan Metode Geometrik

\begin{tabular}{ccccc}
\hline \multirow{2}{*}{ Tahun } & \multicolumn{3}{c}{ Kecamatan } & \multirow{2}{*}{ Total } \\
\cline { 2 - 4 } & Lut Tawar & Kebayakan & Bebesen & \\
\hline 2020 & 21.691 & 16.954 & 41.475 & 80.120 \\
\hline 2021 & 22.104 & 17.277 & 42.266 & 81.647 \\
\hline 2022 & 22.526 & 17.606 & 43.071 & 83.203 \\
\hline 2023 & 22.955 & 17.941 & 43.893 & 84.789 \\
\hline 2024 & 23.393 & 18.283 & 44.729 & 86.405 \\
\hline 2025 & 23.839 & 18.6311 & 45.582 & 88.052 \\
\hline 2026 & 24.294 & 18.986 & 46.451 & 89.731 \\
\hline 2027 & 24.757 & 19.347 & 47.337 & 91.441 \\
\hline 2028 & 25.229 & 19.716 & 48.239 & 93.184 \\
\hline 2029 & 25.710 & 20.091 & 49.159 & 94.960 \\
\hline 2030 & 26.200 & 20.474 & 50.096 & 96.770 \\
\hline
\end{tabular}

\subsection{Analisa Proyeksi Jumlah Pelanggan}

Perusahaan Daerah Air Minum (PDAM) Tirta Tawar Aceh Tengah untuk IKK Bukit Oregon tahun 2019 kondisi eksisting mempunyai kapasitas terpasang sebesar 90 liter/detik dengan jumlah 11.182 SR atau 67.082 orang. Dengan demikian, cakupan layanan IKK Bukit Oregon sebesar 85\%. Proyeksi jumlah pelanggan sampai Tahun 2030 diperlihatkan pada Tabel 4.

Tabel 4 Jumlah Pelanggan Proyeksi Tahun 2020 - 2030

\begin{tabular}{cccc}
\hline Tahun & $\begin{array}{c}\text { Jumlah Penduduk } \\
\text { (Orang) }\end{array}$ & $\begin{array}{c}\text { Presentase } \\
\text { Pelayanan }(\%)\end{array}$ & $\begin{array}{c}\text { Jumlah Pelanggan } \\
\text { Proyeksi (Orang) }\end{array}$ \\
\hline 2020 & 80.120 & $85 \%$ & 68.102 \\
\hline 2021 & 81.647 & $85 \%$ & 69.400 \\
\hline 2022 & 83.203 & $85 \%$ & 70.723 \\
\hline 2023 & 84.789 & $85 \%$ & 72.071 \\
\hline 2024 & 86.405 & $85 \%$ & 73.445 \\
\hline 2025 & 88.052 & $85 \%$ & 74.844 \\
\hline 2026 & 89.731 & $85 \%$ & 77.725 \\
\hline 2027 & 91.441 & $85 \%$ & 79.206 \\
\hline 2028 & 93.184 & $85 \%$ & 80.716 \\
\hline 2029 & 94.960 & $85 \%$ & 82.255 \\
\hline
\end{tabular}




\subsection{Kebutuhan Air Bersih}

Dalam IKK Bukit Oregon Aceh Tengah untuk 1 SR berjumlah 6 orang dan kebutuhan airnya sebesar 60 liter/orang/hari. Hidrant Umum disini tidak dihitung, karena tidak terdapat Hidrant Umum di kota Aceh Tengah. Pada Kebutuhan Non Domestik dihitung dengan menggunakan 30\% dari Kebutuhan Domestik dikarenakan Bangunan Non Domestik yang tidak terlalu banyak. Kebutuhan air bersih untuk jumlah pelanggan diperlihatkan pada Tabel 5 .

Tabel 5 Kebutuhan Air Bersih Untuk Jumlah Pelanggan

\begin{tabular}{ccccc}
\hline Tahun & $\begin{array}{c}\text { Jumlah } \\
\text { Pelanggan } \\
\text { (orang) }\end{array}$ & $\begin{array}{c}\text { Kebutuhan Harian } \\
\text { Rata-Rata (QT) } \\
\text { (liter/detik) }\end{array}$ & $\begin{array}{c}\text { Kebutuhan Harian } \\
\text { Maksimum (Qmaks) } \\
\text { (liter/detik) }\end{array}$ & $\begin{array}{c}\text { Kebutuhan } \\
\text { Jam Puncak } \\
\text { (liter/detik) }\end{array}$ \\
\hline 2020 & 68.102 & 73,777 & 84,843 & 110,665 \\
\hline 2021 & 69.400 & 75,183 & 86,461 & 112,775 \\
\hline 2022 & 70.723 & 76,616 & 88,109 & 114,924 \\
\hline 2023 & 72.071 & 78,077 & 89,788 & 117,115 \\
\hline 2024 & 73.445 & 79,565 & 91,500 & 119,347 \\
\hline 2025 & 74.844 & 81,081 & 93,244 & 121,622 \\
\hline 2026 & 76.271 & 82,627 & 95,021 & 123,941 \\
\hline 2027 & 77.725 & 84,202 & 96,832 & 126,303 \\
\hline 2028 & 79.206 & 85,807 & 98,678 & 128,711 \\
\hline 2029 & 80.716 & 87,443 & 100,559 & 131,164 \\
\hline 2030 & 82.255 & 89,109 & 102,476 & 133,664 \\
\hline
\end{tabular}

Sementara itu kebutuhan air yang diperlukan untuk jumlah penduduk diperlihatkan pada Tabel 6.

Tabel 6 Kebutuhan Air Bersih Untuk Jumlah Penduduk

\begin{tabular}{ccccc}
\hline Tahun & $\begin{array}{c}\text { Jumlah } \\
\text { Penduduk } \\
\text { (orang) }\end{array}$ & $\begin{array}{c}\text { Kebutuhan Harian } \\
\text { Rata-Rata (QT) } \\
\text { (liter/detik) }\end{array}$ & $\begin{array}{c}\text { Kebutuhan Harian } \\
\text { Maksimum (Qmaks) } \\
\text { (liter/detik) }\end{array}$ & $\begin{array}{c}\text { Kebutuhan } \\
\text { Jam Puncak } \\
\text { (liter/detik) }\end{array}$ \\
\hline 2020 & 80.120 & 86,796 & 99,816 & 130,194 \\
\hline 2021 & 81.647 & 88,451 & 101,718 & 132,676 \\
\hline 2022 & 83.203 & 90,137 & 103,657 & 135,205 \\
\hline 2023 & 84.789 & 91,855 & 105,633 & 137,782 \\
\hline 2024 & 86.405 & 93,606 & 107,647 & 140,409 \\
\hline 2025 & 88.052 & 95,390 & 109,698 & 143,085 \\
\hline 2026 & 89.731 & 97,208 & 111,790 & 145,812 \\
\hline 2027 & 91.441 & 99,061 & 113,920 & 148,592 \\
\hline 2028 & 93.184 & 100,949 & 116,092 & 151,424 \\
\hline 2029 & 94.960 & 102,874 & 118,305 & 154,311 \\
\hline 2030 & 96.770 & 104,835 & 120,560 & 157,252 \\
\hline
\end{tabular}

\subsection{Sistem Jaringan Pipa Menggunakan Software Watercad V8-i}

Untuk jaringan pipa menggunakan software Watercad $V 8-i$ hasil parameternya diikuti berdasarkan Pedoman T-09-2005-C PAM BM Badan Litbang Dinas Pekerjaan Umum, diantaranya kecepatan minimum sebesar 0,3 $0,6 \mathrm{~m} /$ detik dan kecepatan maksimum sebesar $6 \mathrm{~m} /$ detik, dan untuk tekanan 
minimum 0,5 - 1 atm dan tekanan maksimum sebesar 10 atm (untuk jenis besi atau baja). Hasil simulasi diperlihatkan pada Tabel 7.

Tabel 7 Hasil Simulasi Masing-Masing Pipa Menggunakan Booster Dengan Software Watercad V8-i

\begin{tabular}{|c|c|c|c|c|c|c|c|c|c|c|c|c|}
\hline Label & $\begin{array}{l}\text { Leng (User } \\
\text { Define) (m) }\end{array}$ & $\begin{array}{l}\text { Start } \\
\text { Node }\end{array}$ & $\begin{array}{l}\text { Stop } \\
\text { Node }\end{array}$ & $\begin{array}{l}\text { Diameter } \\
(\mathrm{mm})\end{array}$ & $\begin{array}{c}\text { MinorLoss } \\
\text { Coefficient } \\
(\text { Local })\end{array}$ & Material & $\begin{array}{c}\text { Hazen- } \\
\text { Williams } \\
\text { C } \\
\end{array}$ & $\begin{array}{l}\text { Flow } \\
(\mathrm{L} / \mathrm{s})\end{array}$ & $\begin{array}{l}\text { Velocity } \\
(\mathrm{m} / \mathrm{s})\end{array}$ & $\begin{array}{c}\text { Headloss } \\
\text { Gradient } \\
(\%) \\
\end{array}$ & $\begin{array}{c}\text { Headloss } \\
\text { (Friction) } \\
(\mathrm{m})\end{array}$ & $\begin{array}{c}\text { Headloss } \\
\text { (Minor) } \\
(\mathrm{m})\end{array}$ \\
\hline P-1 & 19 & R-1 & PMP-1 & 350 & 0,8 & HDPE & 140 & 97,566 & 1,014 & 0,471 & 0,05 & 0,04 \\
\hline $\mathrm{P}-3$ & 80 & $\mathrm{~J}-1$ & $\mathrm{~J}-2$ & 350 & 0,8 & HDPE & 140 & 97,566 & 1,014 & 0,305 & 0,2 & 0,04 \\
\hline $\mathrm{P}-4$ & 74 & $\mathrm{~J}-2$ & $\mathrm{~J}-3$ & 350 & 0,5 & HDPE & 140 & 97,566 & 1,014 & 0,288 & 0,19 & 0,03 \\
\hline $\mathrm{P}-5$ & 40 & $\mathrm{~J}-3$ & $\mathrm{~J}-4$ & 350 & 0 & HDPE & 140 & 97,566 & 1,014 & 0,253 & 0,1 & 0 \\
\hline $\mathrm{P}-6$ & 74 & $\mathrm{~J}-4$ & $\mathrm{~J}-5$ & 350 & 0,2 & HDPE & 140 & 97,566 & 1,014 & 0,267 & 0,19 & 0,01 \\
\hline $\mathrm{P}-7$ & 56 & $\mathrm{~J}-5$ & $\mathrm{~J}-6$ & 350 & 0,2 & HDPE & 140 & 97,566 & 1,014 & 0,271 & 0,14 & 0,01 \\
\hline $\mathrm{P}-8$ & 44 & $\mathrm{~J}-6$ & $\mathrm{~J}-7$ & 350 & 0,2 & HDPE & 140 & 97,566 & 1,014 & 0,276 & 0,11 & 0,01 \\
\hline P-9 & 106 & $\mathrm{~J}-7$ & $\mathrm{~J}-8$ & 350 & 0,2 & HDPE & 140 & 97,566 & 1,014 & 0,263 & 0,27 & 0,01 \\
\hline $\mathrm{P}-10$ & 50 & $\mathrm{~J}-8$ & $\mathrm{~J}-9$ & 350 & 0,2 & HDPE & 140 & 97,566 & 1,014 & 0,274 & 0,13 & 0,01 \\
\hline $\mathrm{P}-11$ & 44 & $\mathrm{~J}-9$ & $\mathrm{~J}-10$ & 350 & 0,2 & HDPE & 140 & 97,566 & 1,014 & 0,276 & 0,11 & 0,01 \\
\hline $\mathrm{P}-12$ & 32 & $\mathrm{~J}-10$ & $\mathrm{~J}-11$ & 350 & 0 & HDPE & 140 & 97,566 & 1,014 & 0,253 & 0,08 & 0 \\
\hline P-13 & 122 & $\mathrm{~J}-11$ & $\mathrm{~J}-12$ & 350 & 0,5 & HDPE & 140 & 97,566 & 1,014 & 0,274 & 0,31 & 0,03 \\
\hline P-14 & 100 & $\mathrm{~J}-12$ & $\mathrm{~J}-13$ & 350 & 0 & HDPE & 140 & 97,566 & 1,014 & 0,253 & 0,25 & 0 \\
\hline P-16 & 26 & $\mathrm{~J}-14$ & PMP-2 & 350 & 0,8 & HDPE & 140 & 97,566 & 1,014 & 0,414 & 0,07 & 0,04 \\
\hline $\mathrm{P}-17$ & 24 & PMP-2 & $\mathrm{J}-15$ & 350 & 0,39 & HDPE & 140 & 97,566 & 1,014 & 0,337 & 0,06 & 0,02 \\
\hline P-18 & 144 & $\mathrm{~J}-15$ & $\mathrm{~J}-16$ & 350 & 0,2 & HDPE & 140 & 97,566 & 1,014 & 0,26 & 0,36 & 0,01 \\
\hline P-19 & 76 & $\mathrm{~J}-16$ & $\mathrm{~J}-17$ & 350 & 0,2 & HDPE & 140 & 97,566 & 1,014 & 0,267 & 0,19 & 0,01 \\
\hline P-20 & 100 & $\mathrm{~J}-17$ & $\mathrm{~J}-18$ & 350 & 0 & HDPE & 140 & 97,566 & 1,014 & 0,253 & 0,25 & 0 \\
\hline $\mathrm{P}-21$ & 50 & $\mathrm{~J}-18$ & $\mathrm{~T}-1$ & 350 & 0,8 & HDPE & 140 & 97,566 & 1,014 & 0,336 & 0,13 & 0,04 \\
\hline
\end{tabular}

Simulasi pada masing-masing junction dilakukan menggunakan boster dengan memanfaatkan software Watercad V8-i dan hasil selengkapnyanya seperti diperlihatkan pada Tabel 8

Tabel 8 Hasil Simulasi Masing-Masing Junction Menggunakan Booster Dengan Software Watercad V8-i

\begin{tabular}{cccc}
\hline Label & $\begin{array}{c}\text { Elevation } \\
(\mathrm{m})\end{array}$ & $\begin{array}{c}\text { Hydraulic } \\
\text { Grade }(\mathrm{m})\end{array}$ & $\begin{array}{c}\text { Pressure } \\
(\mathrm{atm})\end{array}$ \\
\hline $\mathrm{J}-1$ & $1.242,00$ & $1.325,85$ & 8,1 \\
\hline $\mathrm{J}-2$ & $1.242,00$ & $1.325,60$ & 8,08 \\
\hline $\mathrm{J}-3$ & $1.248,00$ & $1.325,39$ & 7,48 \\
\hline $\mathrm{J}-4$ & $1.251,00$ & $1.325,29$ & 7,18 \\
\hline $\mathrm{J}-5$ & $1.257,00$ & $1.325,09$ & 6,58 \\
\hline $\mathrm{J}-6$ & $1.262,00$ & $1.324,94$ & 6,08 \\
\hline $\mathrm{J}-7$ & $1.265,00$ & $1.324,82$ & 5,78 \\
\hline $\mathrm{J}-8$ & $1.269,00$ & $1.324,54$ & 5,36 \\
\hline $\mathrm{J}-9$ & $1.273,00$ & $1.324,40$ & 4,97 \\
\hline $\mathrm{J}-10$ & $1.277,00$ & $1.324,28$ & 4,57 \\
\hline $\mathrm{J}-11$ & $1.280,00$ & $1.324,20$ & 4,27 \\
\hline $\mathrm{J}-12$ & $1.278,00$ & $1.323,87$ & 4,43 \\
\hline $\mathrm{J}-13$ & $1.287,00$ & $1.323,62$ & 3,54 \\
\hline $\mathrm{J}-14$ & $1.290,00$ & $1.323,49$ & 3,23 \\
\hline $\mathrm{J}-15$ & $1.300,00$ & $1.331,00$ & 2,99 \\
\hline $\mathrm{J}-16$ & $1.301,00$ & $1.330,62$ & 2,86 \\
\hline $\mathrm{J}-17$ & $1.308,00$ & $1.330,42$ & 2,17 \\
\hline $\mathrm{J}-18$ & $1.318,00$ & $1.330,17$ & 1,18 \\
\hline
\end{tabular}


Simulasi pada masing-masing pipa dilakukan tanpa menggunakan boster dengan memanfaatkan software Watercad V8-i dan hasil selengkapnyanya seperti diperlihatkan pada Tabel 9

Tabel 9 Hasil Simulasi Masing-Masing Pipa Tanpa Booster Dengan Software Watercad V8-i

\begin{tabular}{|c|c|c|c|c|c|c|c|c|c|c|c|c|}
\hline Label & $\begin{array}{l}\text { Leng } \\
\text { (User } \\
\text { Define) } \\
\text { (m) }\end{array}$ & $\begin{array}{l}\text { Start } \\
\text { Node }\end{array}$ & $\begin{array}{l}\text { Stop } \\
\text { Node }\end{array}$ & $\begin{array}{l}\text { Diameter } \\
(\mathrm{mm})\end{array}$ & $\begin{array}{c}\text { MinorLoss } \\
\text { Coefficient } \\
\text { (Local) }\end{array}$ & Material & $\begin{array}{l}\text { Hazen- } \\
\text { Williams } \\
\text { C }\end{array}$ & $\begin{array}{l}\text { Flow } \\
(\mathrm{L} / \mathrm{s})\end{array}$ & $\begin{array}{l}\text { Velocity } \\
(\mathrm{m} / \mathrm{s})\end{array}$ & $\begin{array}{c}\text { Headloss } \\
\text { Gradient } \\
(\%)\end{array}$ & $\begin{array}{l}\text { Headloss } \\
\text { (Friction) } \\
\text { (m) }\end{array}$ & $\begin{array}{c}\text { Headloss } \\
\text { (Minor) } \\
(\mathrm{m})\end{array}$ \\
\hline P-1 & 19 & R-1 & PMP-1 & 350 & 0,8 & HDPE & 140 & 90 & 0,93 & 0,402 & 0,04 & 0,04 \\
\hline $\mathrm{P}-2$ & 13 & PMP-1 & $\mathrm{J}-1$ & 350 & 0,39 & HDPE & 140 & 90 & 0,93 & 0,352 & 0,03 & 0,02 \\
\hline $\mathrm{P}-3$ & 80 & $\mathrm{~J}-1$ & $\mathrm{~J}-2$ & 350 & 0,8 & HDPE & 140 & 90 & 0,93 & 0,261 & 0,17 & 0,04 \\
\hline P-4 & 74 & $\mathrm{~J}-2$ & $\mathrm{~J}-3$ & 350 & 0,5 & HDPE & 140 & 90 & 0,93 & 0,247 & 0,16 & 0,02 \\
\hline P-5 & 40 & $\mathrm{~J}-3$ & $\mathrm{~J}-4$ & 350 & 0 & HDPE & 140 & 90 & 0,93 & 0,217 & 0,09 & 0 \\
\hline P-6 & 74 & $\mathrm{~J}-4$ & $\mathrm{~J}-5$ & 350 & 0,2 & HDPE & 140 & 90 & 0,93 & 0,229 & 0,16 & 0,01 \\
\hline $\mathrm{P}-7$ & 56 & $\mathrm{~J}-5$ & $\mathrm{~J}-6$ & 350 & 0,2 & HDPE & 140 & 90 & 0,93 & 0,233 & 0,12 & 0,01 \\
\hline P-8 & 44 & $\mathrm{~J}-6$ & $\mathrm{~J}-7$ & 350 & 0,2 & HDPE & 140 & 90 & 0,93 & 0,237 & 0,1 & 0,01 \\
\hline P-9 & 106 & $\mathrm{~J}-7$ & $\mathrm{~J}-8$ & 350 & 0,2 & HDPE & 140 & 90 & 0,93 & 0,225 & 0,23 & 0,01 \\
\hline P-10 & 50 & $\mathrm{~J}-8$ & J-9 & 350 & 0,2 & HDPE & 140 & 90 & 0,93 & 0,235 & 0,11 & 0,01 \\
\hline P-11 & 44 & J-9 & $\mathrm{J}-10$ & 350 & 0,2 & HDPE & 140 & 90 & 0,93 & 0,237 & 0,1 & 0,01 \\
\hline P-12 & 32 & $\mathrm{~J}-10$ & $\mathrm{~J}-11$ & 350 & 0 & HDPE & 140 & 90 & 0,93 & 0,217 & 0,07 & 0 \\
\hline P-13 & 122 & $\mathrm{~J}-11$ & $\mathrm{~J}-12$ & 350 & 0,5 & HDPE & 140 & 90 & 0,93 & 0,235 & 0,26 & 0,02 \\
\hline P-14 & 100 & $\mathrm{~J}-12$ & $\mathrm{~J}-13$ & 350 & 0 & HDPE & 140 & 90 & 0,93 & 0,217 & 0,22 & 0 \\
\hline P-15 & 32 & $\mathrm{~J}-13$ & J-14 & 350 & 0,8 & HDPE & 140 & 90 & 0,93 & 0,328 & 0,07 & 0,04 \\
\hline P-16 & 50 & J-14 & $\mathrm{J}-15$ & 350 & 0,8 & HDPE & 140 & 90 & 0,93 & 0,228 & 0,11 & 0,04 \\
\hline P-17 & 144 & $\mathrm{~J}-15$ & J-16 & 350 & 0,2 & HDPE & 140 & 90 & 0,93 & 0,223 & 0,31 & 0,01 \\
\hline P-18 & 76 & $\mathrm{~J}-16$ & $\mathrm{~J}-17$ & 350 & 0,2 & HDPE & 140 & 90 & 0,93 & 0,229 & 0,16 & 0,01 \\
\hline P-19 & 100 & $\mathrm{~J}-17$ & J-18 & 350 & 0 & HDPE & 140 & 90 & 0,93 & 0,217 & 0,22 & 0 \\
\hline P-20 & 50 & $\mathrm{~J}-18$ & $\mathrm{~T}-1$ & 350 & 0,8 & HDPE & 140 & 90 & 0,93 & 0,228 & 0,11 & 0,04 \\
\hline
\end{tabular}

Simulasi pada masing-masing junction yang dilakukan tanpa menggunakan boster dengan memanfaatkan software Watercad V8-i dan hasil selengkapnyanya seperti diperlihatkan pada Tabel 10

Tabel 10 Hasil Simulasi Masing-Masing Junction Tanpa Booster Dengan Software Watercad V8-i

\begin{tabular}{cccc}
\hline Label & $\begin{array}{c}\text { Elevation } \\
(\mathrm{m})\end{array}$ & $\begin{array}{c}\text { Hydraulic } \\
\text { Grade }(\mathrm{m})\end{array}$ & $\begin{array}{c}\text { Pressure } \\
(\text { atm })\end{array}$ \\
\hline $\mathrm{J}-1$ & $1.242,00$ & $1.333,02$ & 8,79 \\
\hline $\mathrm{J}-2$ & $1.242,00$ & $1.332,81$ & 8,77 \\
\hline $\mathrm{J}-3$ & $1.248,00$ & $1.332,63$ & 8,17 \\
\hline $\mathrm{J}-4$ & $1.251,00$ & $1.332,54$ & 7,88 \\
\hline $\mathrm{J}-5$ & $1.257,00$ & $1.332,37$ & 7,28 \\
\hline $\mathrm{J}-6$ & $1.262,00$ & $1.332,24$ & 6,78 \\
\hline $\mathrm{J}-7$ & $1.265,00$ & $1.332,14$ & 6,48 \\
\hline $\mathrm{J}-8$ & $1.269,00$ & $1.331,90$ & 6,08 \\
\hline $\mathrm{J}-9$ & $1.273,00$ & $1.331,78$ & 5,68 \\
\hline $\mathrm{J}-10$ & $1.277,00$ & $1.331,68$ & 5,28 \\
\hline $\mathrm{J}-11$ & $1.280,00$ & $1.331,61$ & 4,98 \\
\hline $\mathrm{J}-12$ & $1.278,00$ & $1.331,32$ & 5,15 \\
\hline $\mathrm{J}-13$ & $1.287,00$ & $1.331,10$ & 4,26 \\
\hline $\mathrm{J}-14$ & $1.290,00$ & $1.331,00$ & 3,96 \\
\hline $\mathrm{J}-15$ & $1.300,00$ & $1.331,86$ & 2,98 \\
\hline $\mathrm{J}-16$ & $1.301,00$ & $1.331,53$ & 2,85 \\
\hline $\mathrm{J}-17$ & $1.308,00$ & $1.331,36$ & 2,16 \\
\hline $\mathrm{J}-18$ & $1.318,00$ & $1.331,14$ & 1,17 \\
\hline
\end{tabular}

Evaluasi Perpipaan Air Minum Menggunakan Aplikasi Watercad V8-i - Wesli, Indra Kurniawan, Said Jalalul Akbar, Maizuar, Khairullah Yusuf, Joni Arfiandi 


\subsection{Neraca Air (Water Balance)}

Dalam neraca air (water balance) terdapat beberapa perhitungan diantaranya perhitungan curah hujan periode ulang 2 tahun, 5 tahun, 10 tahun, 20 tahun, 25 tahun, 50 tahun dan 100 tahun menggunakan persamaan distribusi gumbel, uji probabilitas menggunakan metode smirnov kolmogorov, dan menghitung debit ketersediaan air menggunakan rumus rasional.

Tabel 11 Debit Ketersediaan Air

\begin{tabular}{ccccccccc}
\hline $\begin{array}{c}\text { Periode } \\
\text { Ulang }\end{array}$ & $\begin{array}{c}\mathrm{R}_{24} \\
(\mathrm{~mm})\end{array}$ & $\begin{array}{c}\mathrm{L} \\
(\mathrm{km})\end{array}$ & $\mathrm{S}$ & $\begin{array}{c}\mathrm{T}_{\mathrm{c}} \\
(\mathrm{jam})\end{array}$ & $\mathrm{C}$ & $\begin{array}{c}\mathrm{I} \\
(\mathrm{mm} / \mathrm{jam})\end{array}$ & $\begin{array}{c}\mathrm{A} \\
\left(\mathrm{km}^{2}\right)\end{array}$ & $\begin{array}{c}\mathrm{Q} \\
\left(\mathrm{m}^{3} / \mathrm{det}\right)\end{array}$ \\
\hline 2 tahun & 195,34 & 892,13 & 0,0009 & 0,3617 & 0,15 & 133,389 & 3191,57 & 17752,54 \\
\hline 5 tahun & 371,39 & 892,13 & 0,0009 & 0,3617 & 0,15 & 253,608 & 3191,57 & 33752,24 \\
\hline 10 tahun & 487,95 & 892,13 & 0,0009 & 0,3617 & 0,15 & 333,203 & 3191,57 & 44345,44 \\
\hline 20 tahun & 599,75 & 892,13 & 0,0009 & 0,3617 & 0,15 & 409,553 & 3191,57 & 54506,69 \\
\hline 25 tahun & 635,22 & 892,13 & 0,0009 & 0,3617 & 0,15 & 433,772 & 3191,57 & 57729,97 \\
\hline 50 tahun & 744,48 & 892,13 & 0,0009 & 0,3617 & 0,15 & 508,379 & 3191,57 & 67659,38 \\
\hline 100 tahun & 852,93 & 892,13 & 0,0009 & 0,3617 & 0,15 & 582,436 & 3191,57 & 77515,47 \\
\hline
\end{tabular}

Selanjutnya dari hasil perhitungan debit ketersediaan air seperti Tabel 11, dapat digambarkan dalam bentuk grafik yang berupa neraca air (water balance).

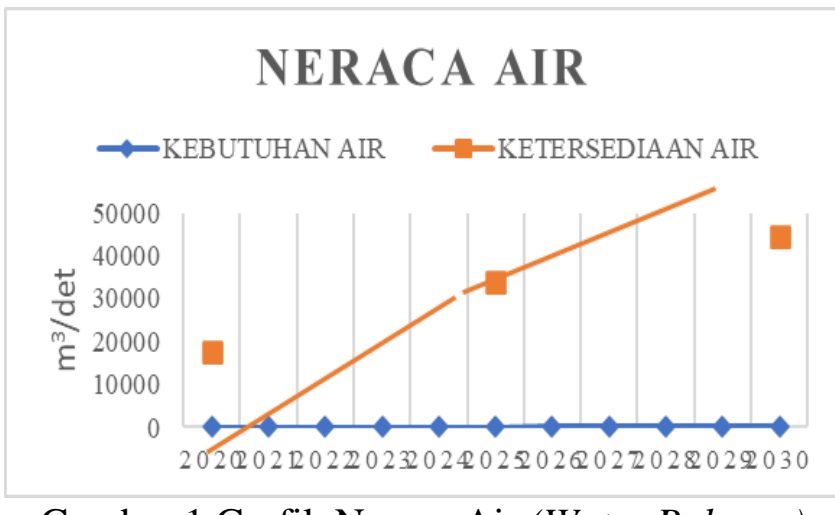

Gambar 1 Grafik Neraca Air(Water Balance)

\section{Kesimpulan dan Saran}

\subsection{Kesimpulan}

Dari hasil analisis ketersediaan air yang ada, danau laut tawar masih bisa digunakan dalam jangka waktu 10 tahun yang akan datang dengan proyeksi kebutuhan air dan hasil simulasi software Watercad V8-i menunjukkan bahwa pipa yang sebelumnya tidak dapat lagi digunakan, dan harus diganti dengan pipa yang lebih kuat dan tahan lama. Pipa sebelumnya berjenis PVC dengan diameter pipa $350 \mathrm{~mm}$ dan diganti dengan jenis pipa HDPE dengan diameter pipa $350 \mathrm{~mm}$.

\subsection{Saran}

Dengan tercukupinya debit ketersediaan air pada masa yang akan datang, diharapkan pada PDAM Aceh Tengah memperbaiki manajemen atau fasilitas yang digunakan, sehingga masyarakat tidak mengalami keluhan yang terjadi. Keluhan yang terjadi pada masyarakat salah satunya terjadi pada air yang tidak jalan menuju rumah-rumah pelanggan, dan jenis pipa dan kapasitas pompa 
diharapkan sudah disiapkan guna menjaga kestabilan air yang akan mengalami pertambahan kebutuhan air dalam waktu yang akan datang. Jenis material pipa diutamakan yang lebih kuat dan tahan lama, sehingga dapat menghemat pengeluaran kedepannya.

\section{Daftar Kepustakaan}

Asgar, La Ode Muhammad, 2016. Perencanaan Sistem Distribusi Air Bersih Desa Gunung Jaya Kecamatan Siotapina Kabupeten Buton, Skripsi. Universitas Halu Oleo, Kendari.

BPS (Badan Pusat Statistik), 2020. Aceh Tengah Dalam Angka Tahun 2019. Kerja Sama Bppeda Kabupaten Aceh Tengah dan Badan Pusat Statistik.

Dharmasetiawan, Martin, 2004. Sistem Perpipaan Distribusi Air Minum. Ekamitra Engineering, Jakarta Selatan.

Kementerian Pekerjaan Umum dan Perumahan Rakyat, 2020. Kondisi SPAM Eksisting Kabupaten Aceh Tengah. Banda Aceh.

Maryanto, Harry, 2013. Perencanaan Teknis Pembangunan Jaringan Distribusi Air Bersih di Daerah Perangkat Selatan Kecamatan Marangkayu Kabupaten Kutai Kartanegara, Jurnal, Universitas 17 Agustus 1945, Samarinda.

Peraturan Menteri Kesehatan Republik Indonesia, 2010. Persyaratan Kualitas Air Minum. Jakarta.

Kementerian Pekerjaan Umum, 2007. Peraturan Menteri Pekerjaan Umum

Nomor: 18/PRT/M/2007 Tentang Penyelenggaraan Pengembangan Sistem Penyediaan Air Minum. Direktur Air Minum, Kementerian PUPR

Wigati, Restu, 2015. Studi Analisis Kebutuhan Air Bersih Pedesaan Sistem Gravitasi Menggunakan Software Epanet 2.0. Jurnal, Universitas Sultan Ageng Tirtayasa.

Zalzilah, Ulfani, 2018. Perencanaan Reservoar Air Bersih Pada Zona 4 PDAM Tirta Daroy Banda Aceh. Tugas Akhir, Universitas Islam Negeri Ar-Raniry, Banda Aceh.

Zamzami, 2007. Sistem Jaringan Distribusi Air Bersih PDAM Tirta Tawar Kabupaten Aceh Tengah. Tesis, Universitas Syiah Kuala, Banda Aceh. 